\title{
CHOSEN PROBLEMS OF ROAD ACCIDENTS ANALYSES IN POLAND
}

\section{WYBRANE PROBLEMY ANALIZ WYPADKÓW DROGOWYCH W POLSCE}

\author{
Jerzy KISILOWSKI ${ }^{1}$, Jarosław ZALEWSKI ${ }^{2}$ \\ (1) Warsaw University of Technology, Faculty of Transport. \\ Warsaw University College of Technology and Business. \\ Politechnika Warszawska, Wydział Transportu, 00-662 Warszawa, ul. Koszykowa 75 \\ Wyższa Szkoła Techniczno-Ekonomiczna w Warszawie, \\ 04-704 Warszawa, ul. Hafciarska 11 \\ (2) Warsaw University of Technology, Faculty of Transport (PhD course). \\ Warsaw University College of Technology and Business (assistant). \\ e-mails: (1) rektorat@wste.pl, (2)jz@wste.pl
}

\begin{abstract}
This article offers classification of car collisions from the point of view of the most frequent accidents and crash tests. The most important problems are the consequences of incomplete control of a car. The article focuses on the safety of road traffic in Poland and presents an attempt to analyze the causes of most frequent collisions and their consequences. It gives statistical data and attempts to analyze the level of road traffic safety. Some important indicators are shown here to compare the situation in France and Poland, which enabled verification of some opinions about road traffic safety in Poland.
\end{abstract}

Keywords: road accident, safety, statistical data.

Streszczenie. Artykuł ten pokazuje klasyfikację zderzeń samochodów z punktu widzenia najczęstszych wypadków drogowych oraz testów zderzeniowych. Skupiono się na bezpieczeństwie ruchu drogowego w Polsce oraz podjęto próbę analizy przyczyn występowania najczęstszych kolizji i ich skutków. Przedstawiono dane statystyczne i podjęto próbę oceny poziomu bezpieczeństwa ruchu drogowego w Polsce. Pokazano kilka wskaźników w celu porównania sytuacji w Polsce i we Francji, co umożliwia weryfikację niektórych opinii na temat bezpieczeństwa ruchu drogowego w Polsce.

Slowa kluczowe: wypadek drogowy, bezpieczeństwo, dane statystyczne. 


\section{Introduction}

Road traffic safety in Poland has become an important issue due to an increase in both the number of registered cars and road accidents. This article presents results of analyses and improvements in driving safety [1]. Countries leading in research towards better safety are those having the greatest experience in this matter, i.e. Sweden, Germany, France, USA and Great Britain. Thanks to combined work of car manufacturers, organizations such as EuroNCAP (assessment of new car safety) and scientific teams it was possible to create state-of-the-art car bodies offering maximum passenger safety which got top marks in crash tests. Except for research into better safety of the car body there are activities aimed at improvement of road traffic. These include the building and modernization of road and motorway networks, as well as regulations to adapt the traffic to the surrounding area. Until now, the main parameter in this respect was the speed limit. The main product of such work in Poland is a stream of publications concerning car body construction, crash mechanics, as well as accident reconstruction and biomechanics of human body at the moment of crash. A different issue is the relationship between road infrastructure and the occurrence of road accidents [2].

The aim of this article is to describe different kinds of car accidents on the basis of the crash theory and consequences of accidents. In its further part, the work discusses different causes of road accidents along with the actual level of road safety in Poland, based on an analysis of statistical data, comparison between some of the indicators in Poland and France, and the relationship between accidents and the condition of road infrastructure. The statistical analysis was made on the basis of the road accidents database for the period between 1995 and 2005. This database was compiled with the use of the Informix software.

\section{Classification of car crashes and the course of the related collisions}

Primarily, road accidents involve contact of one body (here a car) with another one or more bodies (car, man, still barrier) or the ground. To present some basic examples of road accidents as crashes of bodies, it is necessary to make a relevant classification which allows distinction of different types of accidents. Following this train of thought, it appears necessary to describe road accidents and their consequences according to the following guidelines (fig. 1). In order to present road traffic as examples of two-body crash, it is necessary to use a second classification (fig. 2) showing statistical data for the period between 1995 and 2005. It allowed a certain combination allowing separation of accidents resulting from the movement of road vehicles from other road occurrences. 


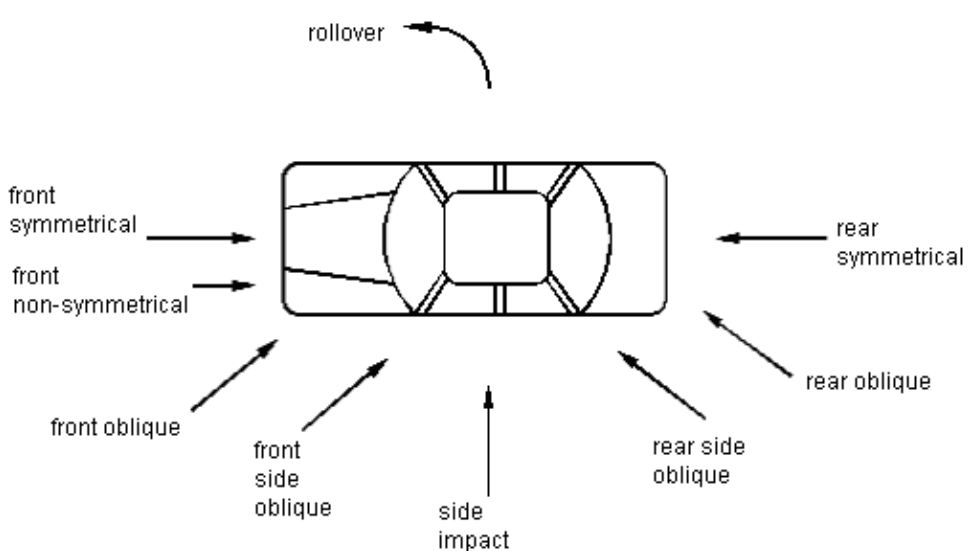

Fig. 1. Division of crashes based on direction of collision. Source: [3].

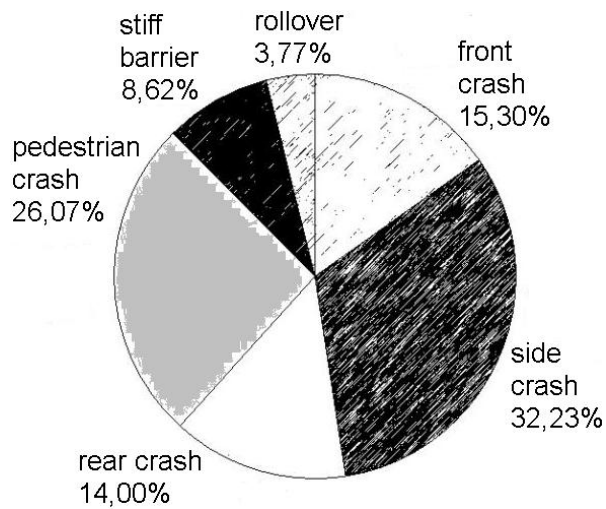

Fig. 2. Percentage of crashes in 1995 - 2004. Source: own research.

\section{Analysis of statistical data}

Road accidents and collisions registered by the police are stored as data in the evidence system of accidents and collisions called SEWiK. On the basis of the statistics received, an attempt to assess the level of road traffic safety in Poland was made. Furthermore, some trends for the future were analysed. A comparison between Poland and France in the years 1998 - 2000 was also developed as France is considered to be the country having better infrastructure and driving culture. 


\subsection{Human factor}

It is believed that the blame for most road accidents lies on the human side. Fig. 3 shows the division of causes for road accidents caused by a human being. In this respect, only pedestrians are a group that really matters. It is noteworthy, however, that while the number of accidents caused by pedestrians fell during the period between 2000 and 2004, those caused by drivers remained at around the same level of 50,000 a year. It is a serious problem and it does not seem that the next years will show any decrease in this area, especially in the face of continuous growth of the number of cars in Poland. The reasons of collisions and accidents should also be searched among factors which influence fluidity and safety of traffic. Fig. 4 shows the number of killed and injured in road accidents in Poland. The period between 1995 and 2004 was taken into account as the comparison was made by relation to 100,000 registered vehicles. The second half of this period seems to have given better results in terms of both the killed and the injured. A clear decrease was reported in the injured rate, to about 400 per every 100, 000 vehicles in 2004. By comparison, between 1995 and 1999 this indicator remained at about 600 . The relative number of persons killed in road accidents after 2000 has stabilized at the level of around 40.

Although there is no evident decrease tendency, we can say that there has been a significant improvement of safety in the period of the last ten years. This is largely due to the development of the car body construction. This factor, along with modern road infrastructure, can lead to further decrease of deaths at the expense of an increase in the number of injuries, e.g. per 100,000 of registered cars. It is also connected with the separation of pedestrians and bicycles from road traffic. In such a case we could expect more side and rear impacts during the lane change. The number of head, pedestrian, and bicycle collisions should decrease. Most rear collisions occur in urban area, so the decrease in their number is connected only with the improvement of the culture and skills of drivers.

The analysis of the changes in the number of road deaths and injuries is continued in table 1 , where the factors mentioned previously are shown in relation to 1,000 accidents in Poland in the period of five years. It is important that the number of deaths oscillate around 110 which allows one to predict some stabilization in this area. In the years $2000-2004$ the number of injuries was around 1,300 per 1,000 accidents. 


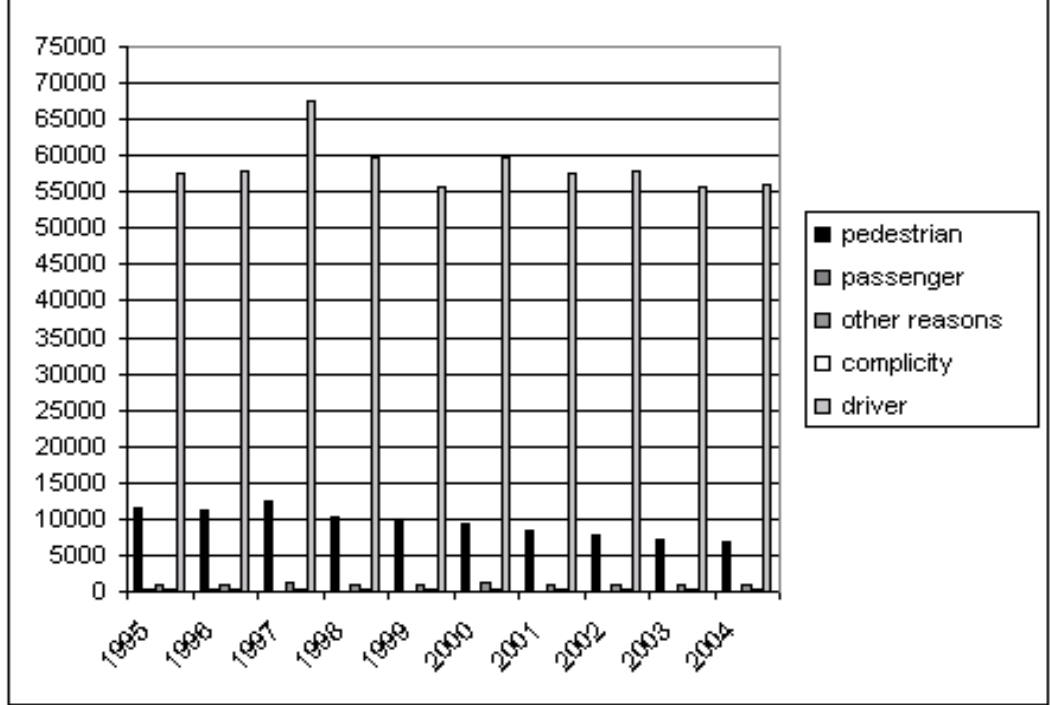

Fig. 3. Causes of accidents resulting from human error. Source: own preparation.

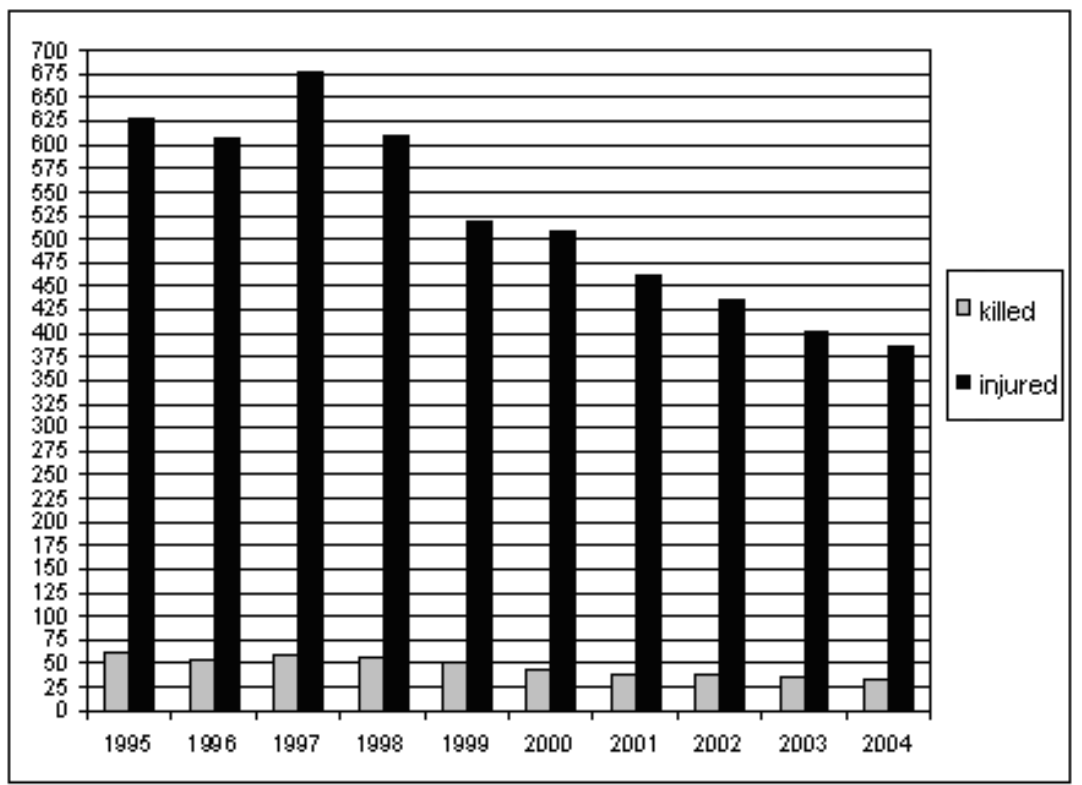

Fig. 4. Number of road deaths and injuries per 100,000 registered vehicles between 1995 and 2004. Source: own research.

Table 2 shows the number of deaths due to accident in Poland in $1998-2000$. This statistics was made to eliminate the factors having the influence on the road traffic safety mainly because of special characteristics of the Polish infrastructure. It is 
a noticeable fact that the number of pedestrians, horse-dawn cart drivers and another types mentioned in table 2 had fallen. Further comparisons prove that one of the basic assumptions of the improvement of road traffic safety should be the solution to the problem of using the same roads by cars, bicycles and all types of users mentioned in table 2 Moreover, limiting the risk of front impacts is also necessary.

Table 1. The number of people killed and injured per 1,000 accidents in Poland, 1995 - 2004. Source: own research.

\begin{tabular}{|c|c|c|c|c|c|}
\hline & \multicolumn{5}{|c|}{ Year } \\
\cline { 2 - 6 } & 2000 & 2001 & 2002 & 2003 & 2004 \\
\hline deaths & 6294 & 5534 & 5827 & 5640 & 5712 \\
\hline injuries & 71638 & 68194 & 67498 & 63900 & 64661 \\
\hline $\begin{array}{c}\text { no. of } \\
\text { accidents }\end{array}$ & 55464 & 52022 & 51773 & 49451 & 49414 \\
\hline $\begin{array}{c}\text { people } \\
\text { killed per } \\
1,000 \\
\text { accidents }\end{array}$ & 113,5 & 106,4 & 112,5 & 114 & 115,6 \\
\hline $\begin{array}{c}\text { people } \\
\text { injured per } \\
1000 \\
\text { accidents }\end{array}$ & 1291,6 & 1310,9 & 1303,7 & 1292,2 & 1308,5 \\
\hline
\end{tabular}

Table 2. The number of people killed in accidents in Poland in1998 - 2000. Source: own research.

\begin{tabular}{|c|c|c|c|c|c|c|c|}
\hline \multirow[b]{2}{*}{$\stackrel{\bar{\Xi}}{\stackrel{\Xi}{D}}$} & \multirow[b]{2}{*}{ 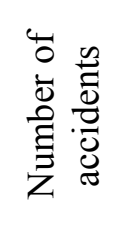 } & \multicolumn{4}{|c|}{ Deaths } & \multirow[b]{2}{*}{$\begin{array}{l}\bar{\sigma} \\
\stackrel{0}{0}\end{array}$} & \multirow[b]{2}{*}{$\begin{array}{r}\text { Total } \\
\text { deaths }\end{array}$} \\
\hline & & Pedestrians & $\begin{array}{c}\text { Motorbik } \\
\text { e, } \\
\text { motorcycl } \\
\text { e drivers }\end{array}$ & $\begin{array}{l}\text { horse- } \\
\text { dawn } \\
\text { cart } \\
\text { drivers }\end{array}$ & $\begin{array}{l}\text { Front } \\
\text { crash }\end{array}$ & & \\
\hline 1998 & 59649 & 2655 & 575 & 15 & 1274 & 4519 & 7080 \\
\hline 1999 & 53915 & 2446 & 643 & 11 & 1323 & 4423 & 6730 \\
\hline 2000 & 55464 & 2226 & 616 & 9 & 1286 & 4137 & 6294 \\
\hline
\end{tabular}

Table 3 shows a comparison. It analyses the number of accidents, deaths and injuries per 100, 000 registered vehicles from 1998 to 2000 in Poland and France. The period indicating the highest increase in the number of vehicles was chosen. 
As observed, the relative values for French road traffic are more than two times smaller for the people killed in accidents.

As for the injured, in both countries the number per 100, 000 registered vehicles fell in the given period. However, this fall is very significant for Poland - it dropped to 100. It means a great improvement in the area of injuries. As far as deaths are concerned, the matter is still unsolved, as France has more cars and better roads. It does not indicate however, that road traffic safety in France is better than in Poland.

Despite the decrease in the number of accidents per 100,000 cars in Poland between 1998 and 2000, the death rate is still twice as high as in France. France reported fewer deaths, and the number of injured people was slightly lower in Poland. This fact can be explained only by greater average speed at which cars move in France on better roads. When comparing relative values it can be seen that the situation was more beneficial in France where, although three times more cars, the rate of deaths per 100000 cars was in the given period slightly lower along with its general decrease in both countries.

To make full assessment of road traffic safety in both Poland and France, a comparison between every type of accident would be necessary. The results would probably show a great deal higher number of parallel impacts (mainly rear) in France. This is connected with roads and motorways, on which such accidents occur. On the other hand, old city and town centres are usually closed for traffic. Besides, there are ring roads, whose existence may influence the small number of side and pedestrian impacts in urban traffic. Although some indicators are close in value, there might be different root causes for this.

On the basis of data in table 3 some conclusions can be made. If problems of infrastructure in Poland had been solved in a different way, which means separation of bicycles and others from car traffic and roads with bands between lanes of different direction, the number of accident deaths could have fallen even by $60 \%$. It means that by comparing relative values, the number of deaths could fall from $45-55$ to about $15-20$ per 100, 000 registered cars.

If one observed a hypothetic decrease of about 5 people over 3 years, then it is obvious how better the situation would be today. The level of road traffic safety would be more competitive in comparison with the countries seen as having cultural drivers. 
Table 3. The victims of accidents for the registered vehicles in the years $1998-$ 2000. The minus in some boxes means that the data was unable to find. However, those factors for France are probably very low. Source: own research.

\begin{tabular}{|c|c|c|c|c|c|c|}
\hline \multirow{2}{*}{} & \multicolumn{2}{|c|}{1998} & \multicolumn{2}{c|}{1999} & \multicolumn{2}{c|}{2000} \\
\cline { 2 - 7 } & Poland & France & Poland & France & Poland & France \\
\hline accidents & 59649 & 124000 & 53915 & $\begin{array}{c}12500 \\
0\end{array}$ & 55464 & $\begin{array}{c}12122 \\
0\end{array}$ \\
\hline deaths & 7080 & 8400 & 6730 & 8000 & 6294 & 8079 \\
\hline $\begin{array}{c}\text { deaths minus } \\
\text { those in table } \\
3.2\end{array}$ & 2561 & - & 2307 & - & 2157 & - \\
\hline $\begin{array}{c}\text { injuries } \\
\text { killed }\end{array}$ & 77560 & 169000 & 68449 & $\begin{array}{c}16800 \\
0\end{array}$ & 71638 & $\begin{array}{c}16200 \\
\text { accidents }\end{array}$ \\
\hline \begin{tabular}{c} 
injured \\
\hline accidents
\end{tabular} & 11,87 & 6,77 & 12,48 & 6,4 & 11,35 & 6,66 \\
\hline $\begin{array}{c}\text { registered } \\
\text { vehicles }\end{array}$ & 1370 & 136,3 & 127 & 134,4 & 129,1 & 133,6 \\
\hline $\begin{array}{c}\text { accidents per } \\
100 \text { 000 } \\
\text { vehicles }\end{array}$ & 469,3 & 380,7 & 409,4 & 347,8 & 393,2 & 360,8 \\
\hline $\begin{array}{c}\text { deaths per } \\
100 \text { 000 } \\
\text { vehicles }\end{array}$ & 55,7 & 25,8 & 51,1 & 24 & 44,6 & 24 \\
\hline $\begin{array}{c}\text { deaths per } \\
100 \text { 000 } \\
\text { vehicles but } \\
\text { minus those } \\
\text { from table 3.2 }\end{array}$ & 20,15 & - & 17.5 & - & 15,3 & - \\
\hline $\begin{array}{c}\text { injuries per } \\
100 \text { 000 } \\
\text { vehicles }\end{array}$ & 610,2 & 518,8 & 519,8 & 503,7 & 507,8 & 482 \\
\hline
\end{tabular}

As for the number of pedestrians, horse-dawn cart drivers, bicycle and motorcycle drivers as well as the victims of front impacts in France, a hypothetical assumption of their lack was made because it was impossible to collect the relevant data. 
However, it is important to take their existence into consideration but probably at a smaller rate than in Poland.

Table 4. The number of accident victims in Poland in 2004 compared with the chosen European countries. Source: own research.

\begin{tabular}{|c|c|c|c|c|}
\hline & Poland & Germany & $\begin{array}{c}\text { Great } \\
\text { Britain }\end{array}$ & France \\
\hline $\begin{array}{c}\text { registered } \\
\text { vehicles }\end{array}$ & 16704000 & 54082000 & 31950000 & 38809000 \\
\hline accidents & 51069 & 339310 & 207410 & 85390 \\
\hline deaths & 5712 & 5842 & 3221 & 5530 \\
\hline injuries & 64661 & 440126 & 277619 & 108272 \\
\hline $\begin{array}{c}\text { accidents per } \\
100 \text { 000 vehicles }\end{array}$ & 305,7 & 1835 & 649,17 & 220 \\
\hline $\begin{array}{c}\text { deaths per } \\
100000 \text { vehicles }\end{array}$ & 34,2 & 31,6 & 10,1 & 14,24 \\
\hline $\begin{array}{c}\text { injuries per } \\
100000 \text { vehicles }\end{array}$ & 387,1 & 2380,3 & 868,9 & 279 \\
\hline
\end{tabular}

According to data in table 4 the number of injured in car accidents per 100000 vehicles in 2004 was smaller than in Germany and Great Britain. There were also fewer accidents per 100000 vehicles than in those two countries. However it is necessary to mention that there are more cars in both Germany and Great Britain as well as in France. As for the death rate, it seems to be the greatest of all four. Relying on the previous considerations we can assume that, if there was the proper road infrastructure in Poland, then those factors would surely be more competitive, given the smaller number of cars than in compared countries.

On the basis of comparing relative values we could ascertain, that despite the growth in the number of cars, the number of accidents, deaths and injuries per 100,000 vehicles in Poland fell during the given 10 years. Moreover, in the last two years, i.e. from 2002 to 2004, some stability in the number of people killed in accidents can be observed. On this conclusion we could assume a stabilization of road traffic safety on a concrete level. Especially some elements of accident had stabilized. The analysis relating to accidents and their casualties between Poland and France in 1998 - 2000 does not allow to synonymously state if the safety level in all European countries is the same. The comparison of the number of accidents, deaths, and injuries proves that in the analyzed period the differences were favourable for France. It is necessary to notice the decreasing tendency of the accident and injured factors for both Poland and France. We can predict that until the present their values are close. 


\section{Conclusions}

From the presented statistical data above it is seen that the most frequent are side and pedestrian impacts. However, the second type does not involve great damage of the car, side impacts can lead to widespread deformations and disturbances in car body geometry. It is caused by the direct contact of stiff bodies with rough surfaces.

The analysis let to determine the chosen relations describing the level of road traffic safety in Poland and France. Those are not the results covering all the problems of assessment. Only a few factors were compared. It can be claimed that road traffic safety level (according to those factors) has stabilized on some concrete level, which is comparable with other European countries. As for injuries, there is not a big difference between the French and Polish situations. The matter which needs improvement is the reduction of the number of people killed in accidents. One of the answers to this question is the Polish road infrastructure. The presented results can lead to determine some directions for further improvement.

\section{References:}

1. Rajchel K.: Prawo drogowe, wypadki, Politechnika Rzeszowska, Rzeszów, 1998.

2. Szczuraszek T.: Bezpieczeństwo ruchu miejskiego, WKŁ, Warszawa 2005.

3. Wicher, J.: Bezpieczeństwo samochodów i ruchu drogowego, WKŁ, Warszawa 2003.

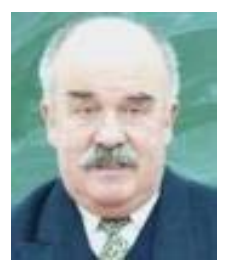

Jerzy Kisilowski, Prof. Full PhD. DSc.: Rector of Warsaw University College of Technology and Business. Works at the Faculty of Transport at Warsaw University of Technology. He specializes in measurement technology, electronics, informational systems, road traffic safety, mathematical modelling. He has over 300 publications in these areas.

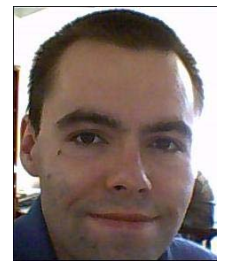

Jarosław Zalewski, MSc: Assistant at the Warsaw University College of Technology and Business. He attends PhD course at the Faculty of Transport (Warsaw University of Technology). He specializes in the problem of contact between road and tires, road traffic safety and statistical data collection. 